\title{
MILINEAL CHARACTER AND BEHAVIOR: \\ DEMOGRAPHIC BONUSES OR THREATS
}

\author{
Ananta Ariefitriansyah Saputra ${ }^{1}$, Moses Glorino Rumambo Pandin ${ }^{2}$ \\ Indonesian Language and Literature Study Program, Faculty of Humanities, Airlangga \\ University \\ ${ }^{2}$ Department of English Language and Literature, Faculty of Humanities, Airlangga \\ University
}

\begin{abstract}
The central problem of this research is the issue of the demographic bonus and the millennial generation whose impact can be an opportunity or a threat to the sustainability and progress of the development of the Indonesian nation. The purpose of this research is to find indicators of millennial character and behavior and to analyze the potential opportunities and threats. This study uses a qualitative overlay by using data collection techniques of observation, interviews, and documentation. The results of the study conclude that the millennial generation has a unique character based on region and socio-economic conditions. One of the main characteristics of the millennial generation is that they are highly literate in digital technology, communicative, and multitasking. Because they were raised by technological advances, this generation has creative, informative, passionate and productive characteristics. If the distinctive characteristics of millennials are understood and facilitated optimally, it will be an opportunity for the development of productive human resources so that they will become the capital of nation building. On the other hand, the characteristics of the millennial generation will become a threat to national development if they are not understood and facilitated according to their potential and passion.
\end{abstract}

Keywords: character, millenial behavior

\section{INTRODUCTION}

Demographic fluctuations and transitions of a country are very favorable when the productive age population (15-64 years) experiences the largest number compared to the proportion of the non-productive age population. This condition can be used as a stepping stone to advance the country concerned. In demography, this condition is called the Demographic Bonus. The Central Statistics Agency (BPS) has estimated that Indonesia will enjoy the demographic bonus era in 2020-2035. At that time, the number of working age population is projected to be at the highest graph in history. The demographic bonus era was also marked by the dominance of the productive age population (15-64 years) over the unproductive population (age 0-14 years and 65+), which can be seen from the low dependency ratio. The dependency ratio is a comparison between the number of people of unproductive age and the number of 
people of productive age. The demographic bonus is an economic advantage caused by the dependency ratio due to a reduction in infant mortality and long-term fertility. The decrease in the proportion of the young population (0-14 years) and the large proportion of the productive population (15-64 years) reduce investment costs to meet their needs, so that these costs can be diverted to use to spur economic growth and family welfare.

The demographic bonus is basically inseparable from the millennial generation. Based on the previous explanation, Indonesia's 2015 dependency ratio of 49.20 indirectly means that the percentage of the productive age population reaches around 67.02 percent of the total population. Furthermore, if the percentage of the productive age population is associated with the percentage of the millennial generation in 2017, which is 33.75 percent of the total population. This means that the contribution of the millennial generation in shaping the structure of the productive age population is quite high, because around 50.36 percent of the total productive age population is basically the millennial generation (assuming the 2015 and 2017 dependency ratios are the same). BPS 2018 data, the number of millennial generations aged 20-35 years reached 24 percent, equivalent to 63.4 million from 179.1 million people who are of productive age (14-64 years). It is not wrong if the millennial generation is called the determinant of Indonesia's future. This is called the demographic bonus.

Analysis of the relationship between demographic bonuses and millennial character and behavior can be arranged in the following framework:

OPPORTUNITY: According to Sita Dewi et al (2018:20): This productive age population is a workforce that can be used to develop Indonesia. This increasing number of workers can be utilized if they are educated, skilled, healthy and have jobs.

THREAT: According to Srihadi (2012:3): The context of the demographic bonus becomes a window of disaster when many people of productive age are not accommodated in employment.

Millennial Character and Behavior: According to Lancaster \& Stillman (2002) Generation Y is known as the millennial generation or millennium, many use instant communication technologies such as email, SMS, instant messaging and social media such as Facebook and Twitter, IG and others, so that with In other words, Generation Y is the generation that grew up in the booming internet era.

\section{METHOD}

The research method in this study uses descriptive qualitative methods, because the research is carried out based on natural conditions (Natural setting). The research method in this research is descriptive qualitative. According to Lexy j. Moleong (2007) defines qualitative descriptive research as research that intends to understand phenomena about what is experienced by research subjects, such as behavior, perceptions, motivations, actions, etc., holistically and by means of descriptions in the form of words and language, at a special context that is natural and by utilizing various natural methods. Data collection techniques used are observation, interview, and documentation techniques. (Sugiyono, 2011:309). Observation techniques are used to determine the actual state of the field. Interview techniques were used to obtain in-depth data from informants and literature study techniques 
were used to obtain documents related to the behavior and character of the millennial generation. The data analysis technique used follows Sugiyono's concept. According to Sugiyono (2013: 335) said that qualitative data analysis consists of three streams of activities that occur simultaneously, namely: data reduction, data presentation, conclusion drawing/verification.

\section{RESULT}

The population of Indonesia over the next few years will continue to increase. Based on data from the Central Statistics Agency (BPS), in 2018 Indonesia's population reached 265 million. Then, in 2024, the number has the potential to increase to 282 million and around 317 million people in 2045. BPS 2018 data, the number of millennials aged 20-35 years reaches 24 percent, equivalent to 63.4 million of 179.1 million people who are aged productive (14-64 years). It is not wrong if the millennial generation is called the determinant of Indonesia's future. This is called the demographic bonus.

\begin{tabular}{|c|c|c|c|}
\hline FACTOR & $\begin{array}{l}\text { FACTOR } \\
\text { BOOMERS }\end{array}$ & GENERATION X & $\begin{array}{l}\text { MILLENIAL } \\
\text { GENERATION Y }\end{array}$ \\
\hline ATTITUDE & Optimistic & Skeptical & Realistic \\
\hline OVERVIEW & $\begin{array}{l}\text { This generation } \\
\text { believes } \\
\text { at the opportunity, } \\
\text { and often too } \\
\text { ideal for } \\
\text { make a change } \\
\text { positive in the } \\
\text { world. } \\
\text { They too } \\
\text { competitive and } \\
\text { looking for a way to } \\
\text { perform from easy to } \\
\text { complex systems. }\end{array}$ & $\begin{array}{l}\text { The generation that } \\
\text { closed, very } \\
\text { independent and } \\
\text { have potential, no } \\
\text { depend on } \\
\text { others for } \\
\text { help them. }\end{array}$ & $\begin{array}{l}\text { Greatly appreciated } \\
\text { difference, more } \\
\text { choose } \\
\text { cooperate } \\
\text { of the } \\
\text { take orders } \\
\text { and } \\
\text { very pragmatic } \\
\text { when } \\
\text { solve the problem. }\end{array}$ \\
\hline $\begin{array}{l}\text { WORK } \\
\text { HABITS }\end{array}$ & $\begin{array}{l}\text { Have a sense of } \\
\text { optimism } \\
\text { tall, worker } \\
\text { hard who wants } \\
\text { award by } \\
\text { personal, believe } \\
\text { on self-change and } \\
\text { development. }\end{array}$ & $\begin{array}{l}\text { Realizing there is } \\
\text { diversity and } \\
\text { global thinking, } \\
\text { balance between } \\
\text { work with } \\
\text { life, nature } \\
\text { informal, self- } \\
\text { reliant, practical } \\
\text { at work, want } \\
\text { having fun } \\
\text { at work, } \\
\text { happy working } \\
\text { with new technology }\end{array}$ & $\begin{array}{l}\text { Choose a flavor } \\
\text { the optimist } \\
\text { high, focus on } \\
\text { achievement, believe } \\
\text { yourself, believe in } \\
\text { moral values } \\
\text { and social, } \\
\text { appreciate diversity. }\end{array}$ \\
\hline
\end{tabular}


Based on the characteristics above, it can be concluded that the millennial generation has different characteristics from the previous generation. Characters with advantages and disadvantages compared to the previous generation. According to Yuswohady in the Millennial Trends article (2016), the millennial generation is the generation born in the early 1980s to 2000. This generation is often referred to as Gen-Y, Net Generation, Generation WE, Boomerang Generation, Peter Pan Generations, and others. They are called the millennial generation because they are the generation that lives at the turn of the millennium. Simultaneously in this era digital technology began to penetrate into all aspects of life. Currently, changes in consumptive lifestyles are very visible in the modern generation or what is commonly referred to as the millennial generation, the millennial generation is a modern generation living at the turn of the millennium. Simultaneously in this era, digital technology began to penetrate into all aspects of life. The millennial generation or also called generation Y was born around 1980 to 2000 . So it can be said that the millennial generation is today's young generation who are currently around 15-34 years old. This age range corresponds to the average age of students who are currently studying in higher education, which is around 19-34 years. Youth Lab (a study institution on Indonesian youth) conducted research in five major cities in Indonesia, namely Jakarta, Bandung, Makassar, Medan, and Malang. The results of the study showed that the millennial generation has a much more creative and informative character. This generation also has a different perspective from the previous generation. The five cities were chosen because they are considered to be indicators of the dynamics of current trends. The research was conducted by dealing directly with and following the activities of millennials, as well as interviewing groups of millennials who became trendsetters. In terms of mindset, the millennial generation is different from the previous generation. This generation was born and raised at a time of economic, political, and social turmoil in Indonesia. The roar of reform is able to have a deep impact on the millennial generation. This generation grows into individuals who are open minded, uphold freedom, are critical and courageous. This is also supported by the current government condition which is more open and conducive.

The various characteristics possessed by the millennial generation mentioned above are the capital to compete in Indonesia's demographic bonus. The role of the government through various policies and regulations to improve the quality of human resources and youth is very much needed. Thus, the millennial generation will increasingly develop and be competent to face these challenges. This will be more effective if each party is able to work together to realize what we are trying to do together. The Indonesian nation should be optimistic about the various potentials possessed by the millennial generation. Therefore, this generation is a big capital to realize the independence of the nation in all aspects. The population of Indonesia over the next few years will continue to increase. Based on data from the Central Statistics Agency (BPS), in 2018 Indonesia's population reached 265 million. Then, in 2024, the number has the potential to increase to 282 million and around 317 million people in 2045. BPS 2018 data, the number of millennials aged 20-35 years reaches 24 percent, equivalent to 63.4 million of 179.1 million people who are aged productive (14-64 years). It is not wrong if the millennial generation is called the determinant of Indonesia's future. This is called the demographic bonus.

If human resources are healthy, intelligent, and productive, it will bring blessings and prosperity to the population. The more abundant human resources of productive age have a 
positive effect on the Indonesian people, because there will be more and more workers for production. This will result in an increase in regional and national income which will ultimately improve the welfare of the community (Kemenpppa: 2018). Indonesia can reap maximum benefits from the demographic bonus, the abundant availability of productive age (millennial) human resources must of course be balanced with improving the quality of education and skills, including its relation to the openness of the labor market. Focus on strengthening the competitiveness of the workforce in entering the global labor market. Strategies that can be taken include improving the quality standards of education and worker competence. Improving the competence of the workforce can be done through government and business/industry partnership programs, as well as between the central government and local governments, as well as improving the governance of the implementation of training programs to accelerate worker certification. In addition, expansion of economies of scale for sectors or sub-sectors that have high productivity. The business world also needs to be encouraged to continuously improve the skills of workers through education and training. As for improving the quality of education, it can be pursued through strategies to increase access, quality, and relevance of education, including developing vocational or vocational education to strengthen innovation capabilities and increase creativity. Skilled workers in Indonesia can come from formal education, namely through vocational education (vocational high schools and polytechnics) and non-formal education, namely through vocational training centers (BLK) and course and training services. This non-formal pathway is expected to provide skills for residents who cannot continue to higher education.

\section{DISCUSSION}

The millennial generation will be able to face the challenges of the demographic bonus while at the same time realizing the independence of the nation provided they must be aware of their potential. If this generation is able to realize its various potentials, an optimistic attitude will arise. This attitude is very important to deal with the demographic bonus fluctuations that will occur in the near future. The demographic bonus will become a pillar of increasing the productivity of a country and become a source of economic growth through the use of productive human resources in the sense that the productive age population is actually able to generate income to meet their consumption needs and have savings that can be mobilized into investment. However, if the opposite happens, where a large number of productive age people are not absorbed by the available jobs in an economy, it will become an economic burden because the productive age population who has no income will remain a burden for the working population and will trigger high unemployment rate.

Haryono Suyono (2013) said that the demographic bonus can be misleading because every policymaker can wait until the "bonus" comes without doing anything meaningful in an effort to find out how the bonus can be used optimally. Nowadays the condition of the population in the young group is quite alarming, especially in terms of education. According to the results of the 2010 SP, it was recorded that the population of Indonesia aged over 6 years who did not/have not attended school reached 14.2 million people. Of these, around 11.00 percent are young (7-24 years old). To note, Indonesia currently faces two main challenges related to employment. First, about 63 percent of the workforce in Indonesia are junior high school graduates or below. This condition has an impact on the productivity and competitiveness of 
the workforce which is relatively low. Second, the education and skills possessed by the workforce are not in accordance with the needs of the industry, causing the industry to experience difficulties in obtaining quality workers.

Indonesia is currently still struggling with two main challenges related to employment. First, the majority of the productive age workforce has a low level of education. Second, the education and skills possessed by the workforce are not in accordance with the needs of the industry, causing the industry to experience difficulties in obtaining quality workers. Indonesia's population from 1945 to 2035 projection. Only $10 \%$ of the productive age population has a higher education degree. Meanwhile, around $65 \%$ of the workforce in Indonesia are junior high school graduates (SMP) or lower, and 25\% are high school graduates (SMA). This condition has an impact on the productivity and competitiveness of the workforce which is relatively low. The quality of human resources is very influential on the competitiveness of companies and industries to move the production sector. Therefore, Indonesia must increase the capacity of its highly educated workforce. The low quality of human resources of productive age will be a burden on the state. If the peak years of the demographic bonus are filled with low-quality human resources, it will be difficult for Indonesia to compete with neighboring countries which also have many productive ages but high-quality human resources. Indonesia must anticipate this if it does not want the demographic bonus to be a disaster. In order for Indonesia to be able to reap maximum benefits from the demographic bonus, the abundant availability of productive age (millennial) human resources must of course be balanced with improving the quality of education and skills, including its relation to the openness of the labor market.

\section{CONCLUSION}

The millennial generation is a generation that has a different character from the previous generation, namely intelligence and familiarity with digital technology. The millennial generation has a unique characteristic, which tends to be creative, has an innovative and productive passion. The distinguishing feature of the previous generation is that the millennial generation cannot be separated from technology in all its activities. This unique millennial behavior and character needs to be understood and supported by the government or the private sector so that it is expected to increase the work productivity of the millennial generation and is expected to accelerate the economic cycle so that the demographic bonus is an opportunity for the Indonesian people to advance their economy through millennials. Another strategy to maximize the potential of the millennial generation in dealing with the demographic bonus is to form new entrepreneurs so that they are able to create jobs and improve the competence of the workforce through training and skill development in facing the openness of the labor market.

\section{REFERENCES}

1. Abi, Abtonius Remigius. 2017. "Paradigma Membangun Generasi Emas Indonesia Tahun 2045". Medan. Universitas St. Thomas. ISSN: 2528-0767 (p) dan 2527-8495 (e). 
2. Hestutomo Restu Kuncoro Demographic bonus and ageing: The mixed blessing of familyplanning. https://www.thejakartapost.com/ Wed, July 12, 2017.

3. Jamal Abdul Nasir and H Tahir, Prolonging the Native Demographic Bonus: An Empirical Evidence. International Journal of Business and Social Science Vol. 2 No. 7; [Special Issue -April 2011]

4. Jati, Wasisto Raharjo,2013; Bonus Demografi Sebagai Mesin Pertumbuhan Ekonomi: Jendela Peluang Atau Jendela Bencana Di Indonesia?

5. Perencanaan Pembangunan Nasional/Bappenas. Siaran Pers BONUS DEMOGRAFI 2030-2040: STRATEGI INDONESIA TERKAIT KETENAGAKERJAAN DAN PENDIDIKAN. Jakarta, 22 Mei 2017

6. Putra, Yanuar Surya. (2016). Theoritical Review: Teori Perbedaan Generasi. Among Makarti, Vol 9 No.18, 123-134.

7. Sri Maryati. 2015. DINAMIKA PENGANGGURAN TERDIDIK: TANTANGAN MENUJU BONUS DEMOGRAFI DI INDONESIA. Journal of Economic and Economic Education Vol.3 No.2 (124 - 136).

8. Sri Moertiningsih Adioetomo. 2013. Memanfaatkan Jendela Peluang Memetik Bonus Demografi . Disampaikan dalam seminar IPADI-BKKBN, 17 Oktober 2014, Jakarta.

9. Yanuar Surya, "Teori Perbedaan Generasi", Putra Among Makarti, Vol.9 No.18, Desember 2016.

10. Yoris Sebastian. 2016." GENERASI LANGGAS MILLENIALS INDONESIA" Jakarta : Gagas Media.

11. Yuswohady. (2016). Millennial Trends 2016. Retrieved June 17, 2019, from https://www.yuswohady.com/2016/01/17/millennial-trends-2016/ 